\title{
The role of imaging in Hirayama disease
}

In the article "imaging in Hirayama disease: A case series," the authors reported three cases of young Indian male patients with Hirayama disease (HD). They all presented the typical clinical features of the disease (i.e., gradual onset and progressive course of unilateral or asymmetric muscular weakness and atrophy in the hand, and ulnar side of the forearm muscles, without sensory or pyramidal signs). ${ }^{[1]}$

Moreover, sagittal magnetic resonance imaging (MRI) scans of cervical spine in neutral position showed focal area of cord atrophy and during neck flexion, an anterior displacement of the posterior dural wall was present with enlargement of the posterior epidural space, which showed contrast-enhancement. After the diagnosis, all patients were conservatively treated with a favorable outcome in two out of three.

Through the description of these cases, the authors pointed out the importance of MRI features in the diagnosis of the disease, underlying the challenge for neurologists and neuroradiologists to early identify this condition.

HD was described in 1959 by Hirayama as a rare, self-limiting juvenile spinal muscular atrophy of the distal upper limbs. The disease predominantly affects young male adults of Asian origin and is characterized by asymmetric motor dysfunctions that may initially be misinterpreted as an atypical form of amyotrophic lateral sclerosis. ${ }^{[2]}$

In $\mathrm{HD}$, symptoms generally progress for 3-4 years after the onset and are followed by a stationary stage; however, the early arrest of the progression is essential for any possibility of improvement.

The pathogenesis of the disease seems to be due to the disproportionate growth of the vertebral column compared to the spinal cord and the following cervical cord compression during neck flexion that induce microcirculatory disturbances responsible of ischemic necrosis of the anterior horn cells, as demonstrated by autoptic findings. ${ }^{[2]}$

The presence of classically described MRI features unequivocally confirms the diagnosis of HD.
It has been demonstrated that in neutral neck position MRI, the detection of segmental, inferior cervical spinal cord atrophy has a diagnostic value with the sensitivity of $59 \%$ and the specificity of $100 \%{ }^{[3]}$ Furthermore, a "sand-watch" - like pattern (i.e., the fact of localized atrophy being between regions of preserved cord architecture) on sagittal views, should lead to further investigations. ${ }^{[4]}$

The diagnosis of HD is straightforward at flexion MRI studies, which often reveals posterior dural detachment from lamina with anterior shift causing spinal cord compression and enlarged posterior epidural space with congested epidural veins. The posterior epidural space is a crescent-shaped space that appears isointense in T1-weighted and hyperintense in T2-weighted images. Uniform contrast-enhancement of this space has been described. ${ }^{[3]}$ Moreover, the venous engorgement of the posterior epidural plexus during active flexion of the cervical spine has been angiographically proven. ${ }^{[5]}$

Conventional MRI may underestimate the extent of cord tissue damage, as demonstrated by Gallo et al., who used nonconventional MRI techniques to assess a patient with HD. Using magnetization transfer and diffusion-weighted MRI of the cervical cord, they found that cord damage in HD extends beyond that seen on routine MR imaging scans. In fact, as a consequence of the chronic ischemic damage in the anterior spinal artery territory, also the corticospinal tracts can be damaged because of their location in the border zone, but remains asymptomatic thanks to the brain cortical reorganization. ${ }^{[6]}$

HD can be treated either conservatively or nonconservatively, and MRI has a crucial role also in the treatment decision. The application of a cervical collar can minimize neck flexion and prevent the progression of muscle weakness and atrophy in the early stages, while surgical decompressive treatment should be applied only to patients with progressive worsening despite conservative treatment, whose radiological findings include compression of the middle and lower cervical cord against the vertebral body, narrowing of the ventral subarachnoid space, and a severe forward shift of the posterior wall of dura during neck flexion. ${ }^{[7,8]}$ 
The evidence within this article strongly supports the idea that an early diagnosis and a prompt therapeutic intervention of HD patients may induce a premature arrest of symptoms progression. The disease-specific features on MRI in neutral position, using both conventional and nonconventional techniques, can help to exclude differential diagnosis (such as compressive myelopathy, radiculopathy, and intrinsic cord pathology) and reveal changes suggestive of the disease that can subsequently be confirmed on dynamic fully-flexed acquisition MRI.

\section{Rosa Cortese, Isabella Laura Simone}

Department of Basic Medical Sciences, Neurosciences and Sense Organs, University of Bari, Italy

Address for correspondence: Prof. Isabella Laura Simone, Department of Basic Medical Sciences, Neurosciences and Sense Organs, University of Bari, Italy Piazza Giulio Cesare, 1170124 Bari, Italy. E-mail: isabellalaura.simone@uniba.it

\section{References}

1. Gupta K, Sood S, Modi J, Gupta R. Imaging in Hirayama disease. A case series. J Neurosci Rural Pract 2016;7:67-9.

2. Hirayama K. Juvenile muscular atrophy of distal upper extremity (Hirayama disease): Focal cervical ischemic poliomyelopathy. Neuropathology 2000;20 Suppl: S91-4.

3. Chen CJ, Hsu HL, Tseng YC, Lyu RK, Chen CM, Huang YC, et al. Hirayama flexion myelopathy: Neutral-position MR imaging findings - Importance of loss of attachment. Radiology 2004;231:39-44.

4. Bede P, Walsh R, Fagan AJ, Hardiman O. "Sand-watch" spinal cord: A case of inferior cervical spinal cord atrophy. J Neurol 2014;261:235-7.

5. Ciceri EF, Chiapparini L, Erbetta A, Longhi L, Cicardi B, Milani N, et al. Angiographically proven cervical venous engorgement: A possible concurrent cause in the pathophysiology of Hirayama's myelopathy. Neurol Sci 2010;31:845-8.

6. Gallo A, Rocca MA, Tortorella P, Ammendola A, Tedeschi G, Filippi M. A multiparametric brain and cord MR imaging study of a patient with Hirayama disease. AJNR Am J Neuroradiol 2006;27:2115-7.

7. Cortese R, Gerevini S, Dicuonzo F, Zoccolella S, Simone IL. Hirayama disease: The importance of an early diagnosis. Neurol Sci 2015;36:1049-50.

8. Konno S, Goto S, Murakami M, Mochizuki M, Motegi H, Moriya H. Juvenile amyotrophy of the distal upper extremity: Pathologic findings of the dura mater and surgical management. Spine (Phila Pa 1976) 1997;22:486-92.

This is an open access article distributed under the terms of the Creative Commons Attribution-NonCommercial-ShareAlike 3.0 License, which allows others to remix, tweak, and build upon the work non-commercially, as long as the author is credited and the new creations are licensed under the identical terms.

\begin{tabular}{|l|l|}
\hline \multicolumn{2}{|c|}{ Access this article online } \\
\hline Quick Response Code: & Website: \\
\hline & www.ruralneuropractice.com \\
\cline { 2 - 3 } & \\
\hline
\end{tabular}

How to cite this article: Cortese R, Simone IL. The role of imaging in Hirayama disease. J Neurosci Rural Pract 2016;7:5-6.

\section{Author Help: Online submission of the manuscripts}

Articles can be submitted online from http://www.journalonweb.com. For online submission, the articles should be prepared in two files (first page file and article file). Images should be submitted separately.

1) First Page File:

Prepare the title page, covering letter, acknowledgement etc. using a word processor program. All information related to your identity should be included here. Use text/rtf/doc/pdf files. Do not zip the files.

2) Article File:

The main text of the article, beginning with the Abstract to References (including tables) should be in this file. Do not include any information (such as acknowledgement, your names in page headers etc.) in this file. Use text/rtf/doc/pdf files. Do not zip the files. Limit the file size to $1 \mathrm{MB}$. Do not incorporate images in the file. If file size is large, graphs can be submitted separately as images, without their being incorporated in the article file. This will reduce the size of the file.

3) Images:

Submit good quality color images. Each image should be less than $4096 \mathrm{~kb}(4 \mathrm{MB})$ in size. The size of the image can be reduced by decreasing the actual height and width of the images (keep up to about 6 inches and up to about $1800 \times 1200$ pixels). JPEG is the most suitable file format. The image quality should be good enough to judge the scientific value of the image. For the purpose of printing, always retain a good quality, high resolution image. This high resolution image should be sent to the editorial office at the time of sending a revised article.

4) Legends:

Legends for the figures/images should be included at the end of the article file. 